\title{
ILMU, ILMUWAN, DAN ETIKA ILMIAH
}

\author{
Kamrani Buseri \\ Fakultas Tarbiyah dan Keguruan IAIN Antasari Banjarmasin
}

\begin{abstract}
Abstrak:
In the process of transferring knowledge from western country, it is inevitable that the pattern of the way of life and habits such as liberalism, hedonism, materialism, empirical and secular attitude was unconsiously adapted. Eventually, science can take man to be more distant from God as a source of spiritual values that is capable of delivering the ultimate goal of human life in the form of peace and harmony. In fact, science has now shifted so that it led to power fight as wellas mastery of the material competition which sometimes violates the social ethics and religion. A scientist is required to realize the negative values that come with science and make a positive factor combined with positive attitude as a beachhead for research in order to achieve the philosophical meaning of science to have a peaceful and prosperous community.
\end{abstract}

\section{PENDAHULUAN}

Membicarakan tentang ilmu, ilmuwan dan etika ilmiah terkait dengan pembicaraan tentang ilmu, ilmuwan dan aktualisasinya dalam penelitian.Ini adalah sesuatu yang menarik, sebab ilmu pengetahuan dewasa ini sedang ramai ditelaah kembali disebabkan kurang mampunya ilmu mengatasi berbagai persoalan manusia.Padahal ilmu pengetahuan sudah begitu sangat pesat perkembangannya, terutama ilmu pengetahuan kealaman atau natural science juga ilmu pengetahuan sosial atau sosial sciences, humaniora, dan agama.

Di sisi lain sekarang ini ilmu menduduki posisi puncak dalam kebudayaan umat manusia. Umat manusia hampir secara mutlak dan berlombalomba untuk mendapatkan ilmu pengetahuan, karena ia selain diharapkan mampu memberikan kemajuan bagi kebudayaan manusia, juga merupakanbagian yang integral dengan pristise suatu bangsa.

Penguasaan ilmu pengetahuan menunjukkan kekuasaan yang membedakan status negara-negara di dunia. ${ }^{1}$ Latar belakang untuk mendapatkan

${ }^{1} \mathrm{JW}$ Schoorl. Modernisasi Pengantar SosiologiPembangunan Negara-Negara Sedang Berkembang, diterjemahkan oleh RG Soekadijo, Cetakan I, (Jakarta: Gramedia, 1981), h. 60. 
ilmu pengetahuan tidak lagi bertujuan untuk mengerti hakikat manusia seperti di zamannya Aristoteles, namun sudah jauh menyimpangkepada yang bernilai praksis dan politis.Perkembangan zaman telah mengubah beberapa aspek kehidupan termasuk ilmu pengetahuan.Manusia melalui nalarnya memperoleh ilmu pengetahuan dan melalui ilmu, pola kebudayaan terus berubah dari yang tradisional ke modern dan seterusnya.Demikian sebaliknya dengan semakin modern suatu kebudayaan maka ilmu yang merupakan bagian di dalamnya memperoleh kemungkinan untuk berkembang lebih maju lagi.Perkembangan kebudayaan dari batu purba, batu baru hingga kebudayaan atom dan nuklir, semuanya membuktikan perkembangan ilmu pengetahuan manusia.

Banyak harapan yang digantungkan kepada ilmu pengetahuan dan teknologi oleh manusia berupa kesejahteraan, kebahagiaan, keamanan, dan pemenuhan segala kebutuhan hidup manusia. Akan tetapi semua harapan itu bisakah dipenuhi oleh ilmu?.Kenyataan demi kenyataan memperlihatkan gejala yang berbeda.Beberapa indikator dari kemajuan ilmu dan teknologi akhir-akhir ini menunjukkan banyaknya dampak negatif yang diakibatkannya terhadap manusia dan kemanusiaan.

Kenyataan seperti itu menimbulkan pertanyaan, dimana letak persoalannya. Apakah terletak pada ilmu itu sendiri, ataukah pada para ilmuwan, dan sebagainya?.

Gejala lain yang cukup menarik bahwa tidak jarang para ilmuwan sendiri ada yang telah lupa dan meninggalkan dasar-dasar keilmuwan, sikap dan etika ilmiah hingga menjadikannya kurang bertanggung jawab. Sikap dan etika ilmiah bukan berada terpisah atau di luar diri ilmuwan, tetapi ia harus menyatu pada saat ilmuwan melakukan tugas pencarian ilmu pengetahuan yakni penelitian. Tanggung jawab ilmiah seperti ini juga berlaku pada saat penerapan ilmu pengetahuan.

Beberapa persoalan di atas itulah yang menjadi perhatian dan dibicarakan dalam tulisan ini.

\section{ILMU PENGETAHUAN \\ Pengertian}

Setiap manusia yang hidup selalu terkait dengan pengetahuan, sebab bagaimanapun manusia selalu menemui problema yang problema itu harus dipecahkan dengan pengetahuan yang dia miliki atau dengan apa yang dia ketahui. 
Sesuai dengan dasar dan sifat manusia yang selalu ingin tahu, maka manusia selalu bergumul dengan pencarian pengetahuan.

Pengetahuan pada hakikatnya merupakan segenap apa yang kita ketahui tentang objek tertentu, termasuk ke dalamnya ilmu. Jadi ilmu merupakan bagian dari pengetahuan yang diketahui oleh manusia di samping berbagai pengetahuan lainnya seperti seni dan agama. ${ }^{2}$

Menurut Hatta, pengetahuan bisa didapat dari pengalaman dan keterangan dengan pembuktian untuk menemukan kausalitasnya. Adapun yang pertama disebut dengan pengetahuan dan yang kedua disebut ilmu. Ilmu senantiasa mengemukakan pertanyaan tentang bagaimana duduknya sesuatu dan apa penyebabnya. ${ }^{3}$

Dari uraian Jujun dan Hatta di atas, sudah jelas perbedaan antara pengetahuan dan ilmu atau sering diistilahkan dengan ilmu pengetahuan. Pengetahuan atau knowledge diperoleh atas dasar pengalaman hidup seseorang, sementara ilmu pengetahuan atau science diperoleh atas dasar penelitian ilmiah sehingga tersusun sebuah temuan berupa teori yang sistematis. Akan tetapi knowledge yang mulanya berasal pengalaman biasa, pada tahap tertentu bisa menjadi science, dan itulah yang sering disebut dengan scientific knowledge.

Ilmu adalah pengetahuan yang teratur tentang pekerjaan hukum kausalitas dalam suatu golongan masalah yang sama tabiatnya baik menurut kedudukannya yang tampak dari luar maupun menurut bangunnya dari dalam. ${ }^{4}$

Menurut sejarahnya, manusia dalam mengatasi problema kehidupannya dengan pengetahuan yang didapat dari pengalamannya, baru kemudian semakin tinggi kebudayaan manusia lahirlah apa yang disebut ilmu pengetahuan.

Ilmu pengetahuan merupakan langkah akhir dari perkembangan mental manusia dan merupakan pencapaian tertinggi dari kebudayaan manusia.Konsepsi tentang ilmu muncul sesudah tampilnya para pemikir besar Yunani sesudah Pythagoras dan para atomis, Plato dan Aristoteles. ${ }^{5} \mathrm{Pada}$ mulanya yang disebut ilmu itu sering disamakan dengan science.Science berasal

${ }^{2} J u j u n$ S. Suriasumantri, Filsafat Ilmu Sebuah Pengantar Populer, (Jakarta: Pustaka Sinar Harapan, 1987),h. 104.

${ }^{3}$ Mohammad Hatta, Pengantar ke Jalan Ilmu dan Pengetabuan, Cetakan IV, Jakarta: PT Pembangunan, 1964), h. 10.

${ }^{4}$ Mohammad Hatta, Pengantar ke Jalan... h. 13.

${ }^{5}$ Ernst Cassirer, Manusia dan Kebudayaan Sebuab Esei Tentang Manusia, diterjemahkan oleh Alois A Nugroho, (Jakarta: Gramedia, Jakarta, 1987), h. 315. 
dari scientia (Latin) yang berarti knowledge. ${ }^{6}$ Sebetulnya orang membedakan istilah knowledge yang diartikan dengan pengetahuan dan science dengan pengetahuan ilmiah.Tetapi sekarang istilah science lebih cenderung dipakai untuk ilmu kealaman.

Menurut The Liang Gie, bahwa dalam penelaahan kepustakaan barat ada lima cakupan yang disebut ilmu (science). Pada abad XVII science sering berarti apa saja yang harus dipelajari misalnya menjahit atau menunggang kuda. Abad berikutnya menunjukkan kepada pengetahuan sistematis.Pengetahuan ini terus meluas hingga termasuk wetenschap (akomulatif knowledge) dan geisteswissenschaften(bumanitis).Pada perkembangan berikutnya timbul pengertian natural science, di sini dibatasi untuk gejala alam, benda-benda dan saling hubungannya.Dalam perkembangan natural science pada bentuk spesifik ilmu, maka timbul denotasi keempat yang merujuk kepada ilmu-ilmu tertentu.Setelahnya timbul denotasi kelima yang menunjuk pengertian science secara kolektif, di mana pada saat orang membicarakan metode ilmu dan pemikiran ilmiah membutuhkan membicarakan semua cabang ilmu. ${ }^{7}$

Dalam mengungkap ilmu, orang seringkali bermula melihatnya dari induk ilmu yakni filsafat, karena dilatarbelakangi bahwa yang disebut ilmu pada awalnya tidak lain adalah ilmu filsafat. Dari filsafat yang bersifat umum kemudian lahir ilmu yang bersifat khusus seperti filsafat alam yang mempelajari benda-benda, gejala-gejala alam, inilah akhirnya yang menjadi natural science.

Dalam membicarakan ilmu pengetahuan terdapat banyak penafsiran.Pertama, istilah pengetahuan itu dapat disamakan pengertiannya dengan wetenschap yang punya pengertian seluas-luasnya karena mencakup segenap pengetahuan manusia yang manapun juga yang tersusun dan terkumpul secara sistematik.

Kedua, istilah ilmu pengetahuan dapat juga diartikan sebagai apa yang dalam bahasa Inggris disebut science yaitu kumpulan pengetahuan yang tersusun secara sistematis yang bahan-bahannya terdapat di luar diri manusia.

Ketiga, istilah ilmu pengetahuan dapat juga dipakai untuk menunjukkan pada suatu kumpulan pengetahuan yang sesungguhnya sudah siap pakai atau applied science. ${ }^{8}$

${ }^{6}$ The Liang Gie, Konsepsi tentang Ilmu, (Yogyakarta: Yayasan Studi Ilmu dan Teknologi, 1984), h. 13.

${ }^{7}$ The Liang Gie, Konsepsi tentang......., hal. 12-18.

${ }^{8}$ Soejono Soemargono, Filsafat Ilmu Pengetahuan, (Yogyakarta: Nur Cahaya,1983), h. 1. 
Menurut Soejono, pengertian ilmu diatas mencakup pengertian yang seluas-luasnya sehingga meliputi ilmu pengetahuan kefilsafatan, ilmu pengetahuan teoritik-positif atau ilmu pengetahuan teoritik-empirik (science)dan ilmu pengetahuan terapan.

Dapat ditarik suatu kesimpulan bahwa yang dimaksud dengan ilmu pengetahuan adalah pengetahuan ilmiah tentang alam-termasuk dirinya-dengan tujuan untuk memperoleh kebenaran.

Kebenaran dapat dipahami bila sesuatu bersifat koheren dan koresponden, yang keduanya dipergunakan dalam cara berpikir ilmiah. ${ }^{9}$ Meskipun ada teori pragmatis, tetapi tampaknya hanya berkaitan dengan waktu, yakni apakah suatu kebenaran koherensi dan korespondensi masih fungsional, jadi agak di luar metode ilmiah. ${ }^{10}$

\section{Fungsi Ilmu Pengetahuan}

Proses kegiatan ilmiah manusia berpuncak dengan ditemukannya ilmu pengetahuan yakni hasil dari proses sistematis, rasional dan metodologis dari usaha manusia untuk mengungkap rahasia alam. Ilmu tak bisa terpisah dari objeknya, maka kegiatan menerangkan dan meramalkan, menerangkan dan memahami bagian penting dari kegiatan pokok sebuah ilmu. ${ }^{11}$

Dalam usaha menerangkan dan meramalkan, maka bagian logis dari yang empiris saling kait mengait akhirnya perjalinan antara yang teoritis dan yang empiris memuncul juga dalam berbagai penjelasan yang harus dibedakan tentang apa sebetulnya yang mau diterangkan, hasilnya:

1. Keterangan logis sebetulnya hanya rengrengan formal, suatu kalkulus;

2. Keterangan sebab akibat (kausal) : sebuah merupakan taf siran mengenai sebuah proses alamiah; timbul pertanyaan mengenai dideterminasi tidaknya segala gejala; ada yang menganggap keterangan itu sebagai kategori mengerti yang mendasar dan berlaku umum (Kant, Walsh);

3. Keterangan final; menerangkan sebuah proses berdasarkan tujuan yang ingin diraih. Dipergunakan terutama pada ilmu-ilmu kehidupan. (Mata adalah anggota badan untuk melihat, dan seterunya). Sejumlah pengarang menolaknya sebagai terlalu antropomorfis.

4. Keterangan fungsional; mencari jawaban lewat pertanyaan mengenai cara kerja. Keterangan fungsional sering menggantikan keterangan final

9Jujun S. Suriasumantri. Filsafat Ilmu... h. 57.

${ }^{10}$ Jujun S. Suriasumantri, Filsafat Ilmu... h. 59.

${ }^{11}$ Van Peursen, C.A., Susunan Imu Pengetahuan Sebuab:

PengantarFilsafatIlmu,diterjemahkan oleh J Drost, (Jakarta: Gramedia, 1985), h. 50-54. 
(misalnya susunan mata dijabarkan dari fungsinya). Para positivistis logis biasanya menolak (3) dan (4);

5. Keterangan historis atau genetis: mengemukakan riwayat terjadinya keterangan. Misalnya kaki kuda berasal dari jari-jari kaki kuda purba, atau geologi menjelaskan lapisan kerak bumi memakai konstelasi-konstelasi lebih tua. Biasanya dilengkapi dengan keterangan kausal. Varian lebih logis terdapat pada J. Piaget: setiap keterangan logis berdasarkan keadaan seimbang, yang dicapai lewat proses perkembangan dan perbaikan;

6. Keterangan analog memakai perbandingan dengan struktur-struktur yang lebih dikenal, misalnya mata memakai kamera, proses-proses informasi pada perusahaan memakai sistem saraf pusat manusia. Kadangkalalebih mirip model daripadaketerangan. ${ }^{12}$

Dalam usaha menerangkan dan memahami (verstehen) mempunyai dua arti, pertama untuk memahami perasaan dan keadaan batin manusia. Memahami orang lain mengandaikan bahwa manusia seakan-akan dapat mengamati perasaannya sendiri atau introspeksi. Kedua, verstehen dipakai untuk menangkap arti suatu teks. Kata-kata diterobosi untuk mengungkap makna yang tersirat. Dalam kaitan dengan verstehen, ada yang dimaksud dengan memahami sekaligus menafsirkan yang disebut hermeneutike. ${ }^{13}$ Dalam hal inilah, Jujun S. Suriasumantri menegaskan kegunaan ilmu untuk menjelaskan, meramal dan mengontrol. ${ }^{14}$

Dengan demikian, dapat ditarik suatu pengertian bahwa fungsi ilmu pengetahuan tidak lain adalah untukmenerangkan,memahami dan meramalkan atau rnengontrol gejala alam termasuk manusia agar manusia bisa mengambil manfaatnya.

\section{MANFAAT DAN DAMPAK ILMU PENGETAHUAN Pengetahuan Pembebas dan Pengikat}

Tidak disangkal lagi bahwa alam yang dahulunya dirasakan oleh manusia sebagai penuh rahasia telah terungkap oleh ilmu pengetahuan. Beberapa kebutuhan hidup manusia dan kemudahan-kemudahan hidup telah dihasilkan oleh ilmu pengetahuan dan teknologi.

Memang menurut kodratnya teknologi bertujuan membebaskan manusia dari urusan-urusan materialnya dan dalam hal ini memang semakin

\footnotetext{
${ }^{12}$ C. A. van Peursen, Susunan Ilmu ... h. 53-54.

${ }^{13}$ C. A. van Peursen, Susunan Ilmu ... h. 55.

${ }^{14}$ Jujun S. Suriasumantri, Filsafat Ilmu ... h. 366.
} 
berhasil. Teknologi telah membebaskan manusia dari pekerjaan rutin, maka manusia sendiri semakin bebas untuk pekerjaan kreatif yang memungkinkan dia mengembangkan dirinya kearah yang lebih baik. ${ }^{15}$

Berbagai temuan ilmu pengetahuan dan teknologi tidak bisa dimungkiri telah membebaskan manusia dari berbagai kesukaran hidup misalnya dengan ditemukan alat transportasi cepat, komunikasi jarak jauh, berbagai temuan bidang kesehatan, komputer dan sebagainya yang dapat disaksikan dewasa ini.

Dampak positif ilmu pengetahuan dan teknologi bagi umat manusia tidak bisa ditutupi lagi dan sejarah perkembangan manusia telah membuktikan hal itu. Palingtidak ada tiga sisi dampak ilmu pengetahuan yaitu segi teknologis, kultural dan filosofis. ${ }^{16}$

Secara terurai ketiga sisi tersebut diutarakan oleh $A B$ Shah dan dari salah satu bagian uraiannya menyatakan "disinilah peran pembebas dari ilmu pengetahuan yang menampilkan diri dalam perspektif sebenarnya. Ilmu pengetahuan telah memungkinkan manusia tumbuh sebagai makhluk manusiawi dan bukannya sekedar segumpal protoplasma, dengan jalan membebaskannya dari belenggu takhayul dan prasangka. Dengan itu ia telah memungkinkan manusia memandang masalah-masalahnya secara objektif dan mencari pemecahannya dengan cara yang berpaedah sesuai dengan martabatnya sebagai makhluk bermoral yang berpikir". ${ }^{17}$ Akan tetapi rupanya efek yang terlalu besar dari pembebasan manusia akhirnya tidak terkendalikan lagi sehingga menjadi bomerang bagi manusia sendiri.

Manusia sekarang tampaknya tidak mampu lagi membedakan antara ilmu pengetahuan dan teknologi sebagai alat bagi manusia untuk mencapai kebahagiannya, tetapi terbalik manusia menjadi budak dari teknologi.Memang menurut Melsen bahwa itu terjadi salah satu sebabnya adalah kekurangan refleksi filosofis dan etis atas bentuk-bentuk baru di bidang ilmu pengetahuan dan praksis berarti segala implikasinya. ${ }^{18}$

Ilmu pengetahuan telah membebaskan manusia dari serba Tuhan.Dahulu orang percaya bahwa alam-matahari beredar, bulan bersinardiatur oleh Tuhan atau dewa tertentu.Setelah ditemukannya hukum alam,

${ }^{15}$ A.G.M. van Melsen,Ilmu Pengetahuan dan Tanggung Jawab Kita, diterjemahkan oleh Bertens, (Jakarta: Gramedia, 1985), h. 111.

${ }^{16}$ AB. Shah, Metodologi Ilmu Pengetabuan, (Jakarta: Yayasan Obor Indonesia, 1985), h. 2.

${ }^{17}$ AB. Shah, Metodologi...h. 9.

${ }^{18}$ A. G. M. van Melsen, Ilmu.... h. 111. 
segala peristiwa alam telah diterangkan oleh hukum yang sudah melekat padanya yang dapat difahami oleh akal manusia. ${ }^{19}$

Akibat pembebasan di atas, manusia merasa kurang terikat dengan Tuhan (agama).Itu pula ada kaitan dengan pengetahuan ilmiah itu strukturnya rasional, isinya empirik dan sipatnya skuler. ${ }^{20}$

Perkembangan ilmu pengetahuan sedikit demi sedikit mengganti kedudukan takhayul dan agama.Ilmu pengetahuan dan teknologi dapat pula menggantikan ideologi yang dianut. Ideologi lain dianggap penghambat demi pencapaian kemajuan dan kesejahteraan, demikian pula agama sehingga menimbulkan konflik-konflik. ${ }^{21}$

Itulah gambaran ilmu pengetahuan don teknologi secara umum, tetapi memang diakui pula bahwa ilmu pengetahuan dalam konteksnya dengan ilmuwan yang melahirkannya, diantara mereka masih ada yang mempercayai adanya Tuhan sebagaimana terlontar dari Enstien. Namun ilmu pengetahuan yang tampak hingga kini, di satu sisi membebaskan manusia dari hal-hal yang negatif, tetapi di sisi lain mengikat manusia begitu ketat hingga melahirkan mazhab scientis yang seakan-akan mempertuhankan ilmu pengetahuan.

\section{Teknologi Mutaakhir Dan Kehancuran}

Hakikat teknologi pada mulanya untuk membantu manusia merubah lingkungan agar bermanfaat bagi kehidupan manusia.Dengan berkembangnya temuan di bidang sains maka kemajuan bidang teknologi juga canggih, akhirnya manusia hampir-hampir tidak mengenal lagi hasil kreasinya sendiri $i_{j}$ serta tidak mampu lagi mengendalikan hasil ciptaannya.

"Ilmu pengetahuan dan teknologi tumbuh dan berkembang dengan cepat melebihi daya serap otak manusia, sehingga tidak dapat memahami seluruh produk ilmu pengetahuan kendatipun sudah memakainya, bahkan menjadi objeknya. Manusia terpragmentasi oleh ilmu pengetahuan sehingga tidak utuh lagi, demikian pula alam lingkungannya.Mula-mula dengan ilmu pengetahuan dan teknologi manusia hendak menguasai alam dan sampai batasbatas tertentu ia berhasil tetapi ia lupa bahwa ia sendiri adalah bagian dari alam dan turut terkuasai oleh ilmu pengetahuan". ${ }^{22}$

${ }^{19}$ AB. Shah, Metodologi...h. 12.

${ }^{20} \mathrm{AB}$. Shah, Metodologi...h. 70.

${ }^{21}$ T. Jacob, Manusia Ilmu dan Teknologi, Pergumulan Abadi dalam Perang dan Damai, (Yogyakarta: Tiara Wacana, 1988), h. 9.

${ }^{22}$ T. Jacob, Manusia, Ilmu.....h. 9. 
Teknologi dewasa ini sudah berada pada pase ke tiga atau tahap puncak.Pada pase pertama manusia langsung menggunakanbahan teknik dari alampada zaman batu.Pada Pase kedua manusia telah mengubah bahan alam kepada hal-hal baru, sedang pada pase ketiga manusia telah menemukan teknologi mesin yang membawa kepada peradaban mesin. ${ }^{23}$ Bahkan lebih puncak lagi dengan menyatunya antara ilmu pengetahuan dan teknologi, atau sebaliknya teknologi mendorong ilmu pengetahuan hingga teknologi peralatan keras telah banyak ditinggalkan oleh taknologi perangkat lunak.

Teknologi modern berbeda jauh dengan teknologi zaman lalu yang masih memberikan kebebasan memilih bagi manusia, tetapi teknologi modern membawa dan membakukan sejumlah nilai-nilainya sendiri seperti teknologi saat ini sangat ditandai oleh rasionalisasi, unsur artifisial sangat menonjol sebagai kebalikan dari yang alamiah, otomatisisme meliputi otomatisisme dalam pemilihan metode, organisasi dan mekanisme juga mampu menghilangkan kegiatan yang bukan teknis menjadi teknis. Segala sesuatu dihitung secara metamatis sehingga tidak ada lagi tempat bagi kebebasan, terus menuntut penerapan teknologi baru, menonjol sifat monolit yaitu mendasarkan pada prinsip pengetahuan secara efisien segala sesuatu, dan universalisme teknologi sampai pada otonomi teknologi yang lama kelamaan nilainya terpisah dari manusia penciptanya. ${ }^{24}$

Beberapa nilai teknologi tersebut pada gilirannya sangat berbahaya dan mengancam manusia seperti tuntutan untuk terus menerus menerapkan teknologi baru.Manusia belum sempat mengadaptasi suatu arus teknologi tibatiba muncul lagi teknologi baru yang meminta untuk diterapkan. Akhirnya manusia menjadi apa yang disebut $\mathrm{T}$ Jacob dengan techno-stress yang bisa berbentuk technosnxietos yang membuat orang menentang adaptasi dan technocentredness yaitu menyebabkan orang percaya betul kepada teknologi.

Masa depan lebih mencemaskan lagi karena penuh schok, ketidakpastian karena lingkungan yang terlalu cepat berubah. Lepasnya teknologi dari laboratorium juga dapat mendehumanisasi manusia. Ilmu pengetahuan dan teknologi juga dapat menggantikan kedudukan manusia sebagai pekerja yang utuh. ${ }^{25}$

\footnotetext{
23Sutarjo A.disusilo JR, Problematika Perkembangan Ilmu Pengetabuan,(Yogyakarta: Yayasan Kanisius, 1983), h. 102-103.

${ }^{24}$ Sutarjo A.disusilo JR, Problematika......h. 111-112.

${ }^{25}$ T. Jacob, Manusia, Ilmu.....h. 11.
} 
Bukan saja manusia yang terkena dampak negatif dari teknologi hasil ciptaannya tetapi yang paling berbahaya jugaadalah kerusakan lingkungan berupa pencemaran besar-besaran serta semakin langkanya sumber daya lingkungan, dan berbagai kerusakan lainnya.

\section{Nilai Ikutan Ilmu Pengetahuan}

Kehadiran ilmu pengetahuan tak bisa dipisahkan dengan budaya dan masyarakat pendukungnya.Dewasa ini sukar memisahkan antara masyarakat barat dengan kemajuan ilmu pengetahuan.dan teknologi sebagai cirinya.

Dalam proses pengalihan pengetahuan dari negeri asalnya barat mau tidak mau, sadar atau tidak ikut terambil pula pola pandangan hidup dan kebiasaan mereka. Ada sementara nilai yang memang bertentangan dengan kepribadian kita bahkan bisa merusak kepribadian kita.Salah satunya adalah liberalisme dan hidonisme yang egoistis menuntut kita mengejar kesenangan sebesar-besarnya selama hidup dan selama ada kesempatan yang akhirnya membawa kepada kerakusan. Nilai lain adalah materialistis. Segala-galanya diukur secara materialis baik kemajuan, kesenangan, sukses, kebahagiaan ${ }_{t}$ kesejahteraan, kualitas hidup dan sebagainya.Nilai lain adalah sentralisasi yang mencakup efisiensi, akibatnya pengetahuan adalah menjadi appendiks pasar, ia tak bebas lagi. Nilai lain pragmatisme. Manusia.lebih bersifat relatif terhadap apa yang terjadi tidak mengantisipasi dan menentukan pilihan sesuai dengan pandangan hidup dan cita-citanya". ${ }^{26}$

Dilain pihak karena pengetahuan manusia didasarkan kepada hal-hal yang empirik, duniawi $i_{1}$ maka manusia terbiasa dengan hal-hal yang duniawi yang pada puncaknya melahirkan sikap skuler, yang benar dan yang harus diyakini adalah sesuatu yang rasional dan empirik.Di luar itu harus diragukan bahkan bisa ditolak.

Ciri empirik dari kebenaran ilmiah berkaitan erat dengan maknanya yang skuler dan skularisme beranggapan bahwa manusia punya hak atas kehidupan materi dan budaya yang sepenuhnya di dunia ini dengan suasana kebebasan dan harga diri bahkan etika sendiri dikaitkan dengan ide yang skuler. $^{27}$

Dilain pihak ilmu pengetahuan yaag dewasa ini menjadi semakin spesifik, sekaligus pula tertutup dengan spesifik lainnya atau disiplin menjadi saling teresolasi.Metode ilmiah membatasi diri hanya pada objek-objek yang

${ }^{26}$ T. Jacob, Manusia, Ilmu.....h. 29-31.

${ }^{27}$ AB Shah, Metodologi Imu.... h. 28-29. 
bisa dicapai secara empiris, karena itu dia berarti menutup diri terhadap pengetahuan dan nilai yang tak empirik seperti yang terdapat pada kebudayaan.Keyakinan mengenai susunan alam, ajaran yang ada pada kebudayaan tentang susunan masyarakat semuanya-Comte- pengetahuan yang lebih bersifat teologis.Demikian pula dalam ilmu-ilmu rasional, penolakan kedudukan nilai-nilai dalam ilmu jelas pula kerena nilai bukanlah objek ilmiah disebabkan tidak empiris. ${ }^{28}$ Pandangan serupa ini jelas terdapat dikalangan positivisme.

Itulah beberapa nilai ikutan i1mu pengetahuan yang sekaligus menunjukkan kekurangan ilmu pengetahuan dan teknologi. Semua itu hendaknya menjadi perhatian kita da lam mengembangkan ilmu pengetahuan yang tampaknya sulit dielakkan.

\section{Ilmu dan Masa Depan Manusia}

Dapat dipastikantidak seorangpun menyangkal tentang pentingnya ilmu pengetahuan bagi kehidupan umat manusia. Kalau tidak demikian tentu bakal terjadi benturan terhadap pelaksanaan pendidikan yang bertujuan untuk memberikan pengetahuan.Melalui pendidikan terprogram diinginkan lahir sejumlah ilmuwan yang berintegritas, dengan lahirnya ilmuwan tersebut manusia dapat memperoleh kemajuan-kemajuan baru dalam hidup dan budayanya. Manusia diharapkan akan lebih sejahtera, lebih aman, lebih terpenuhi segenap kebutuhannya baik lahiriah maupun batiniah. Itulah bunyi harapan kepada ilmu pengetahuan yang nayatanya masih mempunyai delimatis antara dampak positif dan negatifnya.

Dua dampak itu-terutama yang negatif -bukan epistimologi dan ontologinya, tetapi lebih ditentukan oleh aksiologi yakni menyangkut cara memanfaatkan/penggunaan ilmu.

Darmanto Jt memberikan ilustrasi "Dan kalau tak ada yang mencoba untuk mengecam ilmu-ilmu pengetahuan ini, maka pola jawabanpun sudah tersedia; apakah ada ilmu yang tidak manifulatif ?Atau ilmu itu ibarat pistol, tergantung siapa yang pegang. Kalau yang pegang itu Dr. Awaludin Djamin, maka ia dipergunakan untuk menegakkan hukum; kalauyang pegang itu Kusni Kasdut, maka ia dipergunakan untuk merampok hukum". ${ }^{29}$

Ilmu bagi manusia masa lalu atau mesa depan tetap tergantung kepada manusianya. Jadi sekali lagi ilmu pengetahuan hanyalah sebagai alat yang

\footnotetext{
${ }^{28}$ Ignas Kleden, Sikap Ilmiah dan Kritik Kebudayaan, (Jakarta: LP3ES, 1987), xxxv-xxxvi.
}

${ }^{29}$ Jujun S. Suriasumantri, Filsafat Ilmu.... h. 311. 
terserah kepada manusia untuk menggunakan atau tidak alat itu untuk menatap mesa depannya. Mesa depan manusia memang dipengaruhi oleh masa lalu dan masa kini yang gambarannya telah begitu suram. Itu sebagiannya sebagai dampak negatif dari teknologi yang tidak lagi difahami oleh manusia sebagai alat bantunya.

Sebagaimana diutarakan pada sub bab terdahulu, bagaimana nilai-nilai ikutan ilmu pengetahuan telah melumpuhkan manusia dari kemanusiaannya. Keadaan serupa ini tentu akan lebih menyuramkan masa depan manusia. Hal seperti itu tidaklah diharapkan oleh manusia yang sadar akan bahaya di masa depannya.

Manusia yang dasariahnya hidup berbudaya serta mempunyai harga diri yang tertinggi dari seluruh makhluk di persada ini, harus bangkit menatap masa depannya.Hal itu terserah kepada manusia - khususnya ilmuwan - dalam konteks aksiologi.

\section{Tanggung Jawab Ilmuwan}

Berbicara tentang tanggung jawab ilmuwan tentu lebih banyak berkaitan dengan aksiologi, bukan dalam epistemologi semata.

Ada dua kutub berkenaan dengan aksiologi, pertama yang berpandangan bahwa seorang ilmuwan harus netral, tidak ikut bertanggung jawab.Ia hanya dituntut dalam epistemologi, tetapi dari segi aksiologi berlepas diri. Kedua, bahwa seorang ilmuwan dibebani tanggung jawab hingga aspek aksiologi.

Jujun lebih luas melihat bahwa tanggung jawab seorang ilmuwan menyangkut tanggung jawab moral segi profesional dan segi moral. Atau dimaksudkan dengan tanggung jawab segi profesional adalah dalam kaitan epistemologi, mencakup asas kebenaran, kejujuran, tanpa kepentingan langsung, menyandarkan kepada kekuatan argumentasi, rasional, objektif, kritis, terbuka, pragmatis, dan netral dari nilai-nilai yang bersifat dogmatis dalam menafsirkan hakikat realitas. Sedangkan yang dimaksud tanggung jawab moral adalah dalam hubungan membentuk tanggung jawab sosial.yakni pada dasarnya ilmu pengetahuan digunakan untukkemaslahatan manusia. Ilmu digunakan sebagai sarana untuk meningkatkan taraf hidup manusia dengan memperhatikan kodrat manusia, martabat manusia, dan kelestarian lingkungan alam. ${ }^{30}$

Seorang ilmuwan sejati selalu terkait dengan tanggung jawab profesional dan tanggung jawabmoral itu.Dia tidak bisa dipengaruhi oleh

${ }^{30}$ Jujun S. Suriasumantri, Filsafat Ilmu.... h. 6-8. 
kekuatan apapun - politik, kharisma tertentu, kelompok, golongan untuk berbuat tanpa didasari oleh kedua tanggung jawab tersebut.

Sehubungan dengan politik yang menentukan keputusan berkenaan dengan penerapan ilmu dan teknologi dan karena keputusan politik itu mengikat semuaorang dari suatu wilayah politik, maka ilmuwan harus betulbetul mampu bersikap sebagai ilmuwan sejati.

Hubungan antara ilmuwan dan politik banyak dibicarakan yang antara keduanya mempunyai bidang garapan yang berbeda dan keduanya hanya berbeda dari sudut fungsional namun dari segi tanggung jawab moral tetap harus sama.

Ilmuwan - terutama ilmuwan sosial - harus mampu secara objektif memberikan penilaian terhadap kondisi sosial sesuai dengan disiplin ilmunya untuk selanjutnya diketengahkan kepada masyarakat.

Seorang ilmuwan dalam kaitan dengan kondisi seperti yang dikemukakan di atas harus memiliki empat dasar menyangkut (1) kebenaran, (2) kejujuran, (3) tidak mempunyai kepentingan langsung, (4) menyandarkan diri pada kekuatan argumentasi untuk menilai kebenaran. ${ }^{31}$

Untuk mengatasi berbagai problema ilmu pengetahuan, van Melsen menawarkan konsep kewajiban etis dan keinsyafan etis.Kewajiban etis ialah selalu menyadari adanya ketegangan antara yang seharusnya ada dan yang pada kenyataannya ada. Sedangkan keinsyafan etismenyangkut juga ketegangan antara yang sehrusnya ada dan yang pada kenyataannya ada tetapi dalam suatu kerangka yang lebih luas, sebab tidak menyangkut apa yang seharusnya ada begitu saja melainkan apa yang sebetulnya seharusnya ada seandainya kemungkinan-kemungkinan realitas lain daripada keadaan yang nyata. ${ }^{32}$

Ringkasnya secara etis, manusia-ilmuwan-dituntut melalui ilmu pengetahuan untuk menghantarkan kepada tujuan hakiki yaitu memajukan keselamatan manusia dan mewujudkan manusia sebagaimana seharusnya ada.Kearah inilah harapan dunia dewasa ini karena kalau tidak maka kehancuran manusia di ambang pintu.

\section{Kiprah Dan Tanggung Jawab Ilmuwan Peneliti}

Sebagaimana uraian terdahulu bahwa ilmu tak bisa lepas dengan penelitian. Seorang peneliti harus tetap berlandaskan pada sikap ilmiah dan etika ilmiah, agar ia betul-betul berada dalam kerangka dasar pengetahuan.

\footnotetext{
${ }^{31}$ Jujun S. Suriasumantri, Filsafat Ilmu... h. 11.

${ }^{32}$ A.G.M. van Melsen,Ilmu Pengetabuan....... h. 148.
} 
Kerangka dasar ilmu pengetahuan itu mengandung sistem, pengetahuan (ilmiah), kebenaran, dan kebahagiaan umat manusia. ${ }^{33}$ Untuk memenuhi kerangka dasar nomor sistem, pengetahuan, dan kebenaran ilmuwan dituntut untuk berpegang pada epistimologi ilmu, sedangkan untuk memenuhi kebahagiaan umat manusia ilmuwan harusberpegang pada aksiologi.

Seorang ilmuwan dalam penelitian harus sungguh-sungguh mendasarkan diri kepada epistimologi dan aksiologi ilmu, baru ia akan menjadi seorang ilmuwan bukan setengah ilmuwan atau pseudo ilmiah.

Untuk saat ini, ilmuwan sebelum melangkah kedalam penelitian dituntut lebih dahulu untuk menghayati posisi ilmu pengetahuan.Hal itu untuk memudahkan dalam menyusun strategi penelitiannya.Saat ini posisi ilmu tampak tidak seimbang, terutama perkembangan antara ilmu-ilmu kealaman dan kemanusiaan, antara ilmu-ilmu teoritik positif dengan ilmu filsafat sehingga telah banyak dirasakan akibatnya.

Beberapa hal di atas perlu dicamkan sehingga kifrahnya dalam pengembangan ilmu benar-benar bernilai bagi perkembangan dunia dewasa ini.

Seorang ilmuwan peneliti hendaknya mengusahakan agar setiap penelitiannya sampai kepada filsafat suatu ilmu, artinya harus mampu menemukan jawaban yang lebih mendasar daripada sekedar menerangkangejala alam atau menemukan teknologi baru. Dia juga harus mampu menjawab pertanyaan tentang apa sesungguhnya hakikat temuan itu bagi manusia dan kemanusiaan.

Pengertian di atas tidaklah berarti mengembalikan setiap cabang ilmu kepada induknya-filsafat-tetapi setiap ilmu yang spesifik itu mampu merumuskan makna dirinya masing-masing secara lebih hakiki.Inilah beban baru bagi ilmuwan dewasa ini.

Pengembangan ilmu yang sangat tidak seimbang antara ilmu kemanusiaan dan ilmu kealaman haruslah menjadi perhatian ilmuwan dalam penelitiannya. Dewasa ini para ahli dituntut untuk tidak memejamkan sebelah matanya terhadap ilmu-ilmu sosial, kemanusiaan tetapi hendaknya membuka kedua belah mata untuk memandang secara sama sebagaimana dia memandang ilmu kealaman.

Manusia dewasa ini memang dicekoki oleh ilmu-ilmu kealaman yang lebih bersifat menerangkan dan meramalkan, disinilah pula peran ilmuwan peneliti untuk lebih memperhatikan penelitian yang bersifat memahami dan manafsirkan (bermeneutik)

${ }^{33}$ Soejono Soemargono, Filsafat Ilmu...... h. 5. 
Dalam strategi penelitian, ilmuwan harus memperhatikan variabelvariabel negatif ilmu pengetahuan seperti nilai-nilai ikutan ilmu pengetahuan, spesialisasi yang sangat tajam, ketidakseimbangan ilmu kealaman dan kemanusiaan, juga variabel positif dari ilmuwan sendiri misalnya sikap ilmiah, etika ilmiah,tanggung jawab moral, dan profesional. Kedua-duanya harus dijadikan input positif pada saat dia berkifrah dalam penelitian. Berkenaan dengan ilmuwan dan strategi penelitian dapat dilihat pada bagan berikut. 
Bagan: Ilmuwan,Etika Ilmiah, dan Penelitian Ilmiah

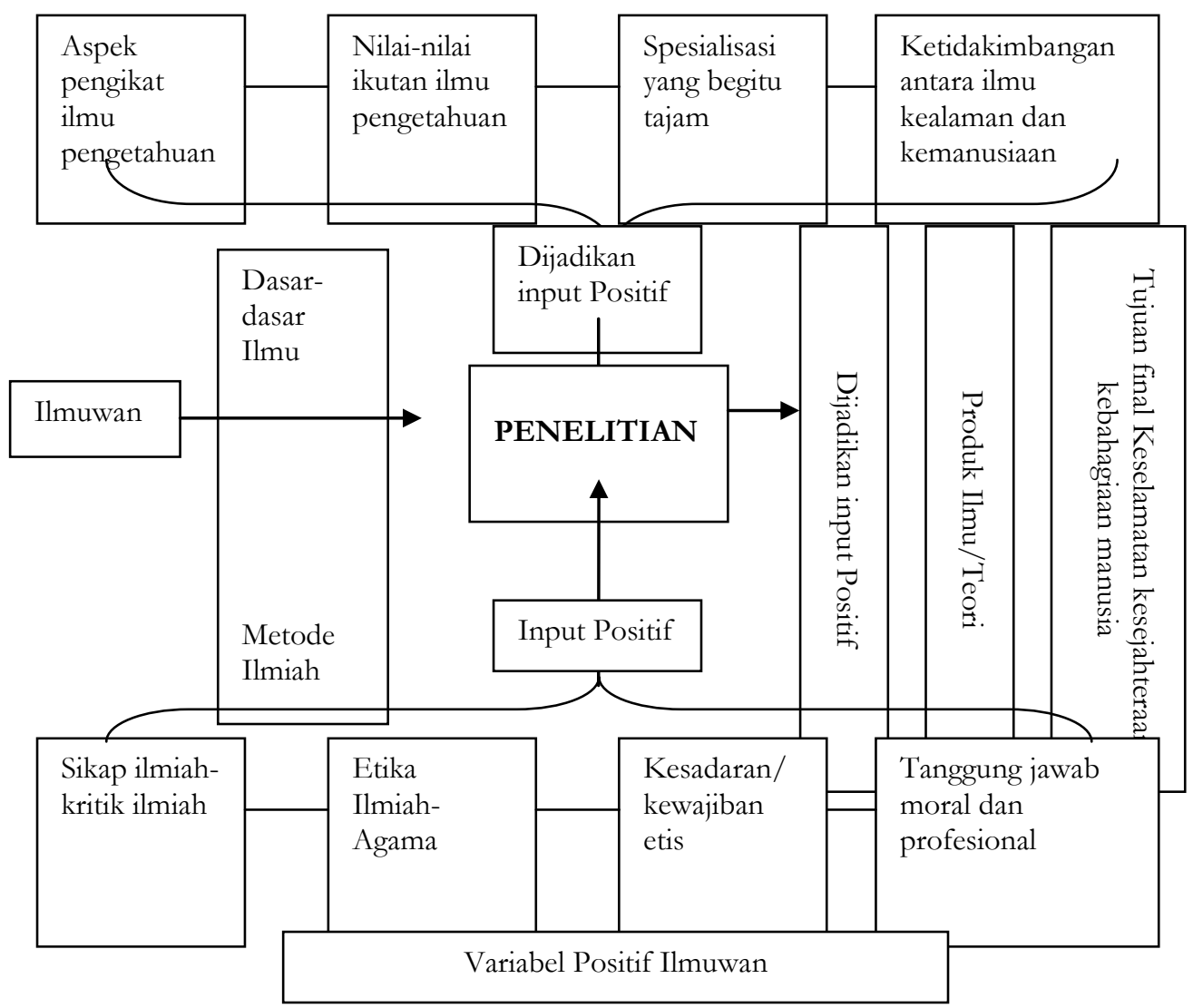

\section{KESIMPULAN}

Ilmu pengetahuan atau pengetahuan ilmiah manusia yang bertujuan untuk menemukan kebenaran tak terlepas dengan manusia (ilmuwan).

Ditinjau dari segi fungsinya, ilmu berfungsi untuk menerangkan dan meramalkan/mengontrol memahami dan menafsirkan gejala alam- termasuk manusia - agar manusia dapat mengambil manfaat daripadanya.

Dalam proses sejarah, ilmu pengetahuan telah berhasil membebaskan manusia dari berbagai problema kehidupan. Manusia bebas dari kebodohan, kerutinan takhayul dan prasangka sehingga memberikan kemungkinan untuk lebih kreatif.Tetapi ilmu pengetahuan dalam perkembangan mutakhir telah menjadi bomerang bahkan mengikat manusia.Manusia telah diikat oleh ilmu 
pengetahuan dengan ikatan yang ketat hingga kehilangan kesadaran diri.Dia menjadi budak ilmu pengetahuan dan teknologi.

Perkembangan ilmu pengetahuan dan teknologi dewasa ini terus semakin menjerat manusia hingga menimbulkan bahaya berupa tumbuhnya penyakit technostress baik dalam bentuk technoanxietos maupun technocenteredness. Bahkan ilmu pengetahuan yang bersumber dari barat membawa pula nilai-nilai ikutan yang bisa merusak kepribadian bangsa seperti liberalistis, materialistis, hidonistis yang egois dan pragmatisme, juga menutup diri dari nilai-nilai non empirik seperti nilai sosial dan agama.

Ilmu dimasa depan tergantung kepada para ilmuwan, oleh karena itu ilmuwan sewaktu berkifrah dalam penelitian harus benar-benar menghayati epistimologi dan aksiologi ilmu. Demikian pula para ilmuwan harus menghayativariabel negatif ilmu untuk dijadikan input positif, demikian pula variabel positif ilmuwan. Keduanya harus dijadikan input positif dalam menyusun strategi penelitian untuk sampai kepada tujuan akhir ilmu pengetahuan yakni menghantar manusia kepada keselamatan, kesejahteraan dan kebahagiaan.

\section{Daftar Pustaka}

A.B, Shah, Metodologi Ilmu Pengetahuan, Yayasan Obor Indonesia, Jakarta, 1986.

Cassirer, Ennst, Manusia dan Kebudayaan Sebuah Esei Tentang Manusia, Diindonesiakan oleh Alois A Nugroho, Gramedia, Jakarta, 1987.

Jujun S. Suriasumantri, Filsafat Ilmu Sebuah Pengantar Populer, Pustaka Sinar Harapan, Jakarta, 1987.

Dialog Tentang Dunia Keilmuwan Dewasa Ini, Gramedia, Jakarta, 1986.

Kleden, Ignas, Sikap Ilmiah dan Kritik. Kebudayaan, Jakarta: LP3ES, 1987.

Koento Wibisono, Arti Perkembangan Menurut Filsafat Positivisme Auguste Comte, Gajahmada University Press, Yogyakarta, 1983.

Mohammad Hatta, Pengantar ke Jalan Ilmu dan Pengetabuan, Cetakan IV, PT Pembangunan, Jakarta, 1964.

Schoorl, J.W., Modernisasi Pengantar SosiologiPembangunan Negara-Negara Sedang Berkembang, Diindonesiakan oleh RG Soekadijo, Cetakan TI, Gramedia, Jakarta, 1981.

Soejono Soemargono, Filsafat Ilmu Pengetabuan, Nur Cahaya, Yogyakarta, 1983. , Filsafat Pengetahuan, Nur Cahaya, Yogyakarta, 1983. 
Sutarjo A.disusilo JR, Problematika Perkembangan Ilmu Pengetahuan, Yayasan Kanisius, Yogyakarta, 1983.

The Liang Gie, Konsepsi tentang Ilmu, Yayasan Studi Ilmu dan Teknologi, Yogyakarta, 1984.

T. Jacob, Manusia Ilmu dan Teknologi, Pergumulan Abadi dalam Perang dan Damai, Tiara Wacana, Yogyakarta, 1988.

Van Melsen, A.G.M., Ilmu Pengetahuan dan Tanggung Jawab Kita, diterjemahkan oleh Bertens, Gramedia,Jakarta, 1985.

Van Peursen, C.A., Susunan Ilmu Pengetahuan Sebuah Pengantar Filsafat Ilmu, Diterjemahkan oleh J Drost, Gramedia Jakarta, $_{1} 1985$. 